\title{
NARRACIÓN EMOCIONAL DE \\ LOS LUGARES DE LA GUERRA \\ EN NARRATIVAS COLOMBIANAS \\ RECIENTES ${ }^{*}$
}

\author{
NARration ÉMOTIONNELLE DES LIEUX DE \\ LA GUERRE DANS DES RÉCENTES NARRATIVES \\ COLOMBIENNES
}

Orfa Kelita Vanegas Vásquez ${ }^{1}$

Artículo derivado de la investigación
"Políticas del miedo e imaginario emocional
de la violencia en narrativas colombianas
recientes".

Cómo citar este artículo: Vanegas Vásquez, O. K. (2019). Narración emocional de los lugares de la guerra en narrativas colombianas recientes. Estudios de Literatura Colombiana 45, pp. 159-176. DOI: https://doi. org/10.17533/udea.elc.n45a09

${ }^{1}$ okvanegasv@ut.edu.co

Universidad del Tolima, Colombia

Recibido: 31.01 .2019

Aprobado: 16.04.2019
Copyright: $\odot 2019$ Estudios de Literatura Colombiana. Este es un artículo de acceso abierto distribuido bajo los términos de la Licencia Creative Commons Atribución No comercial - Compartir igual 4.0 Internacional

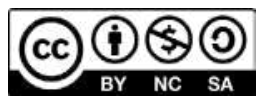

Resumen: se propone un estudio del espacio ficcional como elemento cardinal de lo narrado, que toma sentido y representación a partir de la memoria emocional de los personajes. Las narrativas en cuestión se caracterizan por representar los lugares: urbanos, familiares, rurales, etc., como focos de memoria del pasado violento. La narración afectiva de sucesos relacionados con la violencia política "espacializa" la historia, e identifica el recorrido del terror en proceso de construcción de sus propios escenarios y arquitecturas. Asimismo, el lugar literario suministra asidero para el recobro del pasado, lo personal y la futura memoria.

Palabras claves: narrativa colombiana; emociones; violencia; lugar literario; memoria.

Résumé : Nous proposons une étude de l'espace fictionnel comme élément cardinal du récit, qui prend signification et représentation à partir de la réalité émotionnelle des personnages. Les narrations étudiées se caractérisent par la représentation des lieux : urbains, familiers, ruraux, etc., comme focus de mémoire du passé violent. Le récit affectif des événements liés à la violence politique "spatialise" l'histoire, et identifie le parcours de la peur en procès de construction de leurs propres scénarios et architectures. Également, le lieu littéraire fournit un siège pour la récupération du passé, du personnel et de la mémoire future.

Mots clés : roman colombien; émotions; violence; lieux littéraires; mémoire. 
El presente estudio se circunscribe a un proyecto de investigación más amplio que incorpora lo emocional como figura política y elemento capaz de esclarecer una nueva poética de la violencia, ${ }^{1}$ dilucidar otro imaginario sobre la caótica realidad colombiana y explicar, a su vez, las innovaciones del lenguaje literario que algunos escritores colombianos vienen proponiendo en la primera parte del siglo Xxi. Las novelas abordadas en este texto coinciden en enfocar una vez más la violencia del narcotráfico, la guerra y la criminalidad asociada con este. No obstante, como tratamos de demostrar, en esta ocasión las propuestas ficcionales articulan lo violento desde la particularidad emocional de la víctima o persona inerme. Si bien los novelistas elegidos fijan la atención en las prácticas estéticas de sus antecesores, la escritura de los efectos de la violencia la entienden desde lo emocional traumático más íntimo: el dolor, la desdicha, el miedo, el horror, etc. Lo afectivo, en este orden, se instala en el relato con fuerza protagónica; los elementos ficcionales - tiempo, lugares, tema, personajes - toman profundidad dramática gracias a la intimidad perturbada de quien narra. Sin dejar de lado la alusión a elementos sociohistóricos, que sugieren al lector las causas del conflicto armado, los escritores muestran un marcado interés por nombrar la sensibilidad herida, dar forma a la particularidad emocional del ciudadano común, que sin ser parte activa de la guerra, del narcoterrorismo y demás violencias, se ve arrasado por estas. Cada escritor en cuestión pareciera ir al lugar de los afectos lesionados para luego regresar y contar lo que hay en ellos.

Teniendo en cuenta que lo emocional es el lugar donde la novela logra llegar para descubrir una de las zonas más enigmáticas y ocultas de lo humano sometido a la crueldad atroz del poder, en esta ocasión indagamos los modos como las narrativas elegidas representan y significan la relación entre memoria emocional, violencia política y lugares habitados. Como veremos, los espacios públicos y personales funcionan como instancias dialógicas para discursos y contradiscursos, historia oficial y memoria personal. El seguimiento narrativo de los lugares perdidos, de sitios que la violencia destruyó, ofrece explicaciones al inconformismo íntimo con el presente y al rechazo del estado de cosas de un país, Colombia. La casa, la ciudad, los lugares naturales y zonas campesinas representados en las

$\overline{1} \quad$ Utilizamos el término violencia para referirnos a diversos fenómenos traumáticos, de índole social y política, que han marcado con determinación el devenir de la sociedad colombiana. Este estudio enfoca especialmente la violencia derivada del narcotráfico. Procuramos demostrar que el elemento político es inherente a las diversas violencias que siguen sacudiendo la vida nacional, y que los efectos emocionales de estas, en consecuencia, se establecen como expresión política. 
novelas son índice de una interioridad, emergen de los confines íntimos de quien cuenta, para debatir el ideal de ciudad fundada como civitas: sinónimo de civilización, orden y progreso, y, en derivación, confrontar, a su vez, el imaginario de espacio particular como centro de refugio.

\section{¿Qué tipo de ciudad nos devuelve la memoria?}

Se acepta en el campo literario que la novela ha sido un sitio privilegiado para reescribir y fundar la ciudad. También, para resemantizarla como lenguaje que traduce los cambios de imaginario de lo urbano y su relación con los ritmos económicos y políticos contemporáneos. El escritor hurga los espacios citadinos para proponerlos como "nudo semántico" de una sociedad, un tiempo y una cultura (Jeftanovic, 2007). La ciudad en la ficción se ha reconocido por ser el territorio donde se va tramando la progresiva identificación de los personajes con los sitios que habitan, donde se van localizando los referentes propios y ajenos que fundan el espacio personal (Aínsa, 2006, pp. 166-169). En las novelas que abordamos a continuación, la arquitectura y el trazado de grandes ciudades colombianas - Bogotá, especialmente- y de pequeñas villas o pueblos se hacen desde la crítica hostil y la experiencia del miedo. Los personajes no logran tener el control del territorio que transitan, por habitual que este sea, y están en constante rechazo de lo que ofrece la urbe.

Bogotá, como ciudad capital, consigue en la narrativa colombiana un valor trascendental en tanto ella misma inaugura una nueva noción de lugar: el de la memoria y la historia. Sus coordenadas la sitúan como sitio estratégico de concentración de poder y de noción cívica. La denominación, por caso, de un edificio icónico como Palacio de Justicia, o Casa de Nariño, consagra el discurso gubernativo que, mal que bien, forma parte de una memoria histórica consciente de sí misma, es decir, significativa de un legado político que se admite como herencia. El carácter disímil con que los autores identifican la capital es indicativo de la complejidad de su realidad. Giraldo (2001), glosando la idea de Italo Calvino, propone que Bogotá, en la escritura, sería una de esas ciudades diversas que se suceden sobre el mismo suelo y bajo el mismo nombre. A tenor de la vertiginosidad con que transcurre la vida de la nación, las metáforas de esta ciudad "han sido inquietantes y extremas en los últimos años, pues se dan simultáneamente el afán de reconstruirla en determinados momentos históricos, y la afirmación de un inmediato presente caótico, apocalíptico, tenebroso o desencantado" (p. 118). 
Los lugares emblemáticos de Bogotá, además de ser reconocidos por la ficción como núcleo y parte de una historia y memoria nacional, son foco de innumerables recuerdos personales y de la experiencia emocional del espacio capitalino. Oportuno resulta aclarar aquí que lo emocional lo entendemos como fenómeno coligado al marco moral, social e histórico en el que se produce. Las emociones públicas y personales son decisivas en los hábitos y pensamientos de una cultura. El enfoque de los afectos, bajo este ángulo, es heredero de los postulados spinozianos que proponen las emociones como tipo de ideas que se manifiestan psíquica y corporalmente con disímiles grados de intensidad y de diversos modos. ${ }^{2}$ Entendida como gesto racional, la emoción, en tanto concepto, relativiza su rasgo natural, preconsciente y biológico, a la vez que rescata su ambigüedad cultural y semántica. Por esta razón, cuando la novela explora la memoria emocional de los espacios vividos, indaga en el corazón mismo de los procesos socioculturales, en la relación que los afectos establecen con la construcción del cuerpo social, y en la importancia que estos adoptan en los eventos, intercambios y transformaciones.

En El ruido de las cosas al caer (2011), por ejemplo, la figuración de la Plaza de Bolívar como lugar simbólico del poder político colombiano e ícono que conmemora al Libertador, es, asimismo, sitio expresivo de lo íntimo-emocional; un espacio vivido donde Ricardo Laverde se toma su última foto, antes de ser asesinado (Vásquez, 2011, pp. 25-26). Una foto que Yammara, narrador central, utiliza como "pretexto" para contar la experiencia afectiva de la capital; que es aprovechada por la escritura como desencadenante de los sucesos. La memoria particular del protagonista, al enfatizar en el pasado propio, al recorrer los lugares donde sintió amenazada su vida por el narcoterrorismo, altera el registro oficial del pasado de la nación. La escritura recala en lo emocional lacerado para recuperar la realidad intangible derivada de la violencia del narcotráfico.

Vásquez se sirve también del poema "Ciudad de sueño", de Aurelio Arturo, con la intención de ambientar la ciudad transitada por sus protagonistas. En el epígrafe de El ruido... se lee: "Y ardían desplomándose los muros de mi sueño, ¡Tal como se desploma gritando una ciudad!" (Vásquez, 2011); y en las últimas páginas, cuando el protagonista ha dado

$\overline{2} \quad$ Lo emocional comprendido con sus elementos racional, cognitivo e histórico se desliga de las teorías del "giro afectivo" que defienden la emoción como especie de "energía nomádica" o impulso visceral escindido de la conciencia, aunque manifiesto en el cuerpo. Adoptamos las posturas teóricas de parte de la filosofía política y de la historia de las emociones para debatir el rasgo presentista y universalista que en variados estudios se quiere dar a los afectos. 
orden a su memoria y narrado una versión personal de la Bogotá vivida entre los años ochenta y noventa, cita: "Yo os contaré que un día vi arder entre la noche / una loca ciudad soberbia y populosa [...] Yo, sin mover los párpados, la miré desplomarse, / caer, cual bajo un casco un pétalo de rosa" (p. 254). Estos versos, publicados en 1929, son pensados en la narración como imagen profética. El poema referido se articula en la escritura de manera reveladora. Es inevitable advertir que predice las mayores revueltas del siglo xx desatadas en las calles capitalinas: la violencia bipartidista a causa del asesinato de Gaitán; la barbarie política derivada de la confrontación entre guerrillas y Gobierno: la toma del Palacio de Justicia, por ejemplo, y la desencadenada por el narcotráfico. De esta manera, la Bogotá de la memoria del personaje se adapta a los versos de Aurelio Arturo, entra en ellos llenando sus resquicios, "como el hierro fundido llena siempre el molde que le ha tocado" (Vásquez, 2011, p. 255). La ciudad que arde deja de ser así una imagen metafórica para imponerse como aplastante realidad sobre los héroes. La novela, en efecto, tiene la particularidad de explorar los modos como los grandes acontecimientos históricos influencian las vidas pequeñas, las vidas minúsculas de cada persona (Vásquez, 2018). Sin liberarse de la historia nacional que lo contextualiza, el recuerdo íntimo de sitios históricos señala otra verdad en la escritura. En continuo paralelismo o de manera entrecruzada a la memoria gubernamental, la vivencia de la ciudad por parte de los personajes funda, a su vez, una memoria emocional que exterioriza otra narración de los sucesos del país.

El centro de la capital colombiana demolido por la violencia política se representa igualmente en El incendio de abril (2012), segunda novela de la Trilogía del 9 de abril, de Miguel Torres. Esta vez, la agresión proviene de la furia de los habitantes ante el asesinato de Jorge Eliécer Gaitán, el 9 de abril de 1948, momento que se conoce como El Bogotazo. Las plazas, calles y edificios oficiales de Bogotá son, por enésima vez, en la narrativa el eje de articulación del pasado violento y de la experiencia individualizada de este. Historia nacional y memoria personal se entrecruzan en la escritura de los espacios citadinos:

Al llegar a la séptima veo arder el hermoso edificio de la Gobernación, vecino a la iglesia de San Francisco. Frente a ese incendio hay dos tranvías quemados y las ruinas de otro en la Séptima, frente al lugar donde fue asesinado Gaitán [...] Del otro lado se ven las manzanas que arden del Parque Santander hacia el norte [...] Un puñado de hombres empieza a disparar contra el ejército desde el centro de 
la plaza. Dos de ellos se encaraman al pedestal de la estatua de Nariño y disparan sirviéndose del prócer como escudo [...] La plaza es un espanto. San Victorino, un laberinto infernal (Torres, 2012, pp. 204, 214).

Lo referido en la cita anterior no se acomoda a las abstracciones del discurso oficial, se nutre especialmente de los detalles íntimos y de aquellas cosas sensibles que solo parecen tener importancia para quien las vive y narra como parte de la experiencia propia. Enlazado a lugares específicos de Bogotá, donde toma forma, el caos nacional deja de ser una somera representación del pasado, un dato histórico, cuando es transformado por la escritura de Torres en un relato afectivo. La ciudad, enfatizan De Certeau, Giard y Mayol (2010), "solo vive al preservar todas sus memorias", ella no es exclusivo producto de la historia, se sostiene sobre la experiencia, es resultado del acontecimiento (p. 45). De tal modo, la aparición de la capital en la ficción, como espacio estratégico sobre el cual preguntar por la realidad nacional, se establece en forma de figura semántica que significa la desintegración íntima, el estado emocional de la persona en contextos de violencia extrema. La ciudad textual evidencia la transformación de los lugares cotidianos en indudables sitios del miedo.

Al hilo de estas ideas, no sobra comentar que, frente a la dimensión que Torres da a la capital colombiana, resulta igualmente significativo el simbolismo adoptado por el mapa de Bogotá en la primera página de la novela, pues la ciudad textual lo excede en sus límites. El mapa, como esquema representativo de una Bogotá programada para funcionar, amplifica su dimensión con los acontecimientos vividos por los protagonistas. La "Bogotá textual" se sustrae al lenguaje totalizante, al discurso ordenador y oficial, del que el mapa es fiel índice.

El énfasis narrativo en la memoria personal de los lugares emblemáticos de la urbe intensifica el simbolismo conmemorativo de tales lugares, mientras reescribe para el presente la historia colombiana. Frente a la Historia oficial, entendida como una reconstrucción problemática e incompleta de aquello que ya no es más, una escueta representación del pasado, la memoria individual es un fenómeno siempre actual, está en evolución permanente. Abierta a la dialéctica del recuerdo y de la amnesia, la memoria se nutre de emociones particulares y pertenece al sujeto vivo y a su palabra (Nora, 1984, pp. XVII-XXV). Así, entonces, la recordación íntima de los héroes ficcionales se instituye en la novela como elemento vivificador de la Historia colombiana. A través de la evocación de la ciudad sentida, 
la Historia nacional entra en la narración como cosa viva, se despoja de su armadura temporal y oficial, y se actualiza como fenómeno susceptible a una continua revitalización y reescritura. El recurso literario de escenificar acontecimientos históricos del país como sucesos experimentados por los protagonistas en lugares citadinos emblemáticos obra en el pasado nacional con una fuerza capaz de transmitir para el presente toda la carga simbólica de la historia política de Colombia. Historia/ciudad/memoria aparecen ligadas por la palabra en un "presente inacabado", en una continuación viva de los sucesos.

El recorrido de la escritura de los autores colombianos por sitios específicos, que son nomenclaturas reconocidas socialmente, para fusionarlas al testimonio del derrumbe del país, advierte de las condiciones sobre las que se ha construido el imaginario de nación. Llevar a escena la estatua de un prócer que está siendo abaleada o el incendio de edificaciones gubernativas gira en alegoría de los modos como la nación se ha conformado. La naturaleza nemotécnica de los lugares en la ficción traza el recorrido violento que caracteriza a Colombia desde su nacimiento. Los escombros y restos de la guerra parecen ser los elementos fundamentales que moldean lo nacional en el discurso literario. Las ruinas de los lugares representativos de la memoria oficial se resitúan en el entramado narrativo como cruda metáfora de la calamidad política y su repercusión, en el seno social y la vida del ciudadano común.

En las narrativas en cuestión, los recursos retóricos que figuran los espacios urbanos elucidan la faceta íntima de los personajes. Si bien los acontecimientos simbólicos del pasado han sido ampliamente documentados como hechos concretos — número de muertes, análisis económicos, ciudades y pueblos implicados, razones políticas, etc.-, la realidad afectiva derivada de esos acontecimientos poco se reconoce o se reduce a un testimonio abstracto, a una descripción escueta y deshumanizada. La trama urbana que la narrativa construye se anuda entonces al elemento emocional, impalpable, para nombrar lo que se desgasta u oculta tras el registro público. Las cifras cuantitativas y racionalizadas son transformadas por la escritura en experiencia anímica, haciendo de la historia oficial y la ciudad normada un espacio experimental, lugar donde la verdad intangible de la violencia logra mostrarse, nombrarse y, por tanto, adquirir realidad. El rastro invisible que deja la violencia política en la vida social adquiere forma y volumen en las imágenes emocionales de ciudad que las novelas proponen. 
El espacio citadino, con todo lo que contiene, como analiza Campra (1989), se levanta con materiales que no solo provienen de canteras, aserraderos y fundiciones, sino también de los archivos de la memoria personal y de la suma de experiencias de quien lo transita y lo narra. "Las ciudades están hechas de ladrillos, de hierro, de cemento. Y de palabras [...] ya que es el modo en que han sido nombradas, tanto como los materiales con que se las construyó, lo que dibuja su forma y su significado" (p. 103). De esta manera, para Torres y Vásquez, la urbe literaria no funciona como límite exterior del universo de lo humano; se convierte en índice de la interioridad del personaje. Los lugares van ligados a lo propio, surgen de los confines de lo más íntimo para narrar una memoria afectiva del país.

\section{Quiebres afectivos del espacio personal}

Delirio (2004), de Laura Restrepo, de la misma manera que la novela de Vásquez, espacializa el impacto de la violencia del narcotráfico en la Bogotá de los noventa. Aquí, aunque hay constante alusión a los lugares públicos: universidad, restaurantes, bares, avenidas, etc., prevalece la convivencia en el espacio privado, el recinto familiar. La mirada narrativa se desplaza del lugar público hacia la casa, al sitio personal. La propuesta de escritura de Restrepo indaga las relaciones de la burguesía bogotana con Pablo Escobar; la narración devela la faceta más oscura de la élite capitalina, su ambición de dinero y de poder, y sus transacciones con el narcotráfico. La familia de la protagonista central, Agustina, es tropo indicativo de tal situación.

En Delirio es recurrente la referencia a los lugares de infancia, en especial a la casa familiar, y si bien este tipo de espacio tradicionalmente ha sido metáfora del "paraíso material" (Bachelard, 2000, p. 30), la escritora lo representa como cuna de hostilidad y desdicha. Cuando se deja impregnar del clima psíquico-emocional derivado de las problemáticas nacionales, la casa de infancia como "espacio feliz" pierde todo simbolismo de bienestar y protección. En el recuerdo de Agustina priman las imágenes de un hogar donde la figura autoritaria del progenitor invade cada espacio y es fuerza que demuele al más vulnerable. La caracterización de Carlos Vicente Londoño - padre de la heroína; vinculado con el lavado de dinero del narcotráficose asocia, en múltiples momentos, con pasajes de violencia desmesurada, como cuando una tarde de domingo familiar, en la sala de la casa, tumba a patadas a Bichi, el hijo menor: situación que deja al descubierto la infidelidad del padre, la traición familiar y el resentimiento entre padres, 
hijos y hermanos (Restrepo, 2004, p. 220). Inclusive, la escritura coliga el estremecimiento que produce la presencia del progenitor con la conmoción de los personajes ante la ola de terrorismo que sacude a la capital:

[...] la noche de la bomba de Paloquemao [...] la radio anunciaba cuarenta y siete muertos más un número impreciso de cadáveres entre las ruinas [...] la tía Sofi me contó que por la ventana había visto cómo se levantaba sobre la ciudad un hongo de humo de doscientos metros de alto, y cuando le averigüé si a Agustina la había afectado mucho, me contó que tras despertarse con el cimbronazo, se había levantado muy exaltada diciendo que esa era la señal, ¿la señal de qué, niña? La señal de que debo prepararme para la llegada de mi padre [...] Mi padre va a venir a visitarme (p. 174).

Este pasaje deja percibir el cambio que ha sufrido el hogar como cuna para el refugio. Si en determinado momento la casa natal se asoció con el bienestar y el ambiente donde viven los seres protectores (Bachelard, 2000, p. 30), opuesta a "un afuera" amenazante que desintegra el ensueño y hunde al sujeto en la desazón, Delirio se desvía de este tipo de significación para hacer del lugar familiar - acogedor, seguro- una prolongación más del espacio citadino - perturbador, peligroso-, desencadenante de la angustia y el miedo. La casa no funciona como amparo del mundo exterior; ella se convierte asimismo en topos de agresión; de hecho, es el punto inicial de interacción con las realidades violentas que aplastan al país.

En oposición a los sitios públicos y habitaciones familiares, "el techo de la casa era uno de los lugares donde nos sentíamos libres" (Gamboa, 2012, p. 69), expresa Manuel, narrador de Plegarias nocturnas. Aquí la casa se establece igualmente como lugar de contienda, como microcosmos de lo urbano o ciudad a escala, donde se advierte la caótica vida nacional de la primera década del siglo Xxi. El techo de la casa familiar, como sitio exterior, elevado, fuera del dominio de los otros, funciona como espacio ideal para aspirar a realidades diferentes; para escapar de la vida mediocre y del caos doméstico, que se recrudece con los nocivos cambios de imaginario de nación e identidad abanderados durante el Gobierno de Uribe Vélez (20022010). A diferencia del refugio hogareño de la tradición artística y literaria, cuyo acogimiento se garantiza con el amor fraterno y la mirada consentida de los padres, la vida del hogar en la novela de Gamboa está envuelta en un ambiente emocional tenso, derivado de las circunstancias gubernativas del país. El clima familiar se enrarece a razón del choque violento entre las diferentes inclinaciones políticas de padres e hijos: 
Respete a nuestro presidente, jovencita, que es el primer colombiano que se levanta a trabajar [...] si usted puede dormir tranquila y seguir yendo a estudiar [...] es porque él está allá, velándole el sueño [...] ¿Ah, sí?, ¿vela mi sueño?, dijo Juana, no fregués, y [...] ¿vela por los cuatro millones de desplazados?, ¿por los cadáveres N.N. de las fosas comunes que tiene este puto país? No, papá, no te engañes [...] Papá se contuvo para no dar un puñetazo en la mesa o tirar su vaso contra la pared [...] los días y las noches eran infernales en ese horrendo manicomio (Gamboa, 2012, pp. 64-67).

El respeto, el apoyo y el amor filial se desintegran en las acaloradas discusiones, amenazas y actos de odio. La casa, como adentro primordial, no ofrece las bases para afirmar la identidad propia. La habitación, la mesa del comedor, la sala de estar, núcleos donde se gestan los afectos por la familia, se origina el pensamiento, se dan los desahogos y se producen los recuerdos, obliteran su condición de refugio cuando la calamidad política del país emponzoña la convivencia. La serie de imágenes de la vida familiar, encadenadas semánticamente y con connotaciones cercanas a la realidad violenta que transcurre en los barrios de Bogotá y el escenario nacional -Falsos positivos, ${ }^{3}$ desapariciones, asesinatos políticos, abuso militar para garantizar la "seguridad democrática" - ubican la casa de infancia como un sitio más en crisis. La escritura de Gamboa, al igual que la de Restrepo, rompen el estereotipo de la morada hogareña como espacio de protección ante la amenaza y de recuperación de un pasado feliz y de la identidad perdida, para proponerla como lugar del rencor y la desesperanza, como sitio en el que se elabora un lenguaje y un simbolismo que verifica el estado anímico y afectivo del sujeto y de la sociedad colombiana de las últimas décadas.

Nos permitimos mencionar en este estudio otros espacios igualmente circunscritos al lugar personal entre ellos el jardín. La novela de Rosero, Los ejércitos (2007), introduce su trama ubicando a los personajes centrales en un amplio jardín, indicativo del regocijo y encuentro. Se entra a la realidad ficcional siguiendo la mirada indiscreta y gozosa de un anciano que espía a su vecina desnuda mientras esta toma el sol en el jardín. El narrador, subido a una escalera apoyada en un naranjo, mientras recoge los frutos, proyecta una visión paradisiaca de su propio jardín, y del jardín contiguo, el de la vecina, quien vitaliza el panorama edénico con su cuerpo desnudo, libre, expuesto voluntariamente a la mirada del protagonista:

$3 \quad$ Ejecuciones extrajudiciales cometidas por unidades militares de las Fuerzas Armadas de Colombia. Las víctimas eran asesinadas por soldados para obtener ganancias personales, pues el Gobierno de Uribe Vélez reconocía económica y simbólicamente a los comandos que más guerrilleros dieran "de baja". 
La mujer del brasilero, Geraldina, buscaba el calor de su terraza, completamente desnuda, tumbada bocabajo en la roja colcha floreada. A su lado, a la sombra refrescante de la ceiba, las manos enormes del brasilero merodeaban sabias por su guitarra, y su voz se elevaba, plácida y persistente, entre la risa dulce de las guacamayas; así avanzaban las horas en su terraza, de sol y de música (Rosero, 2007, p. 11).

Frente a esta imagen plácida del jardín, es necesario advertir que, si bien tal sitio aparece al inicio de la narración como refugio sensorial y de embeleso, donde la naturaleza colorida y la sensualidad femenina le dan un tono pintoresco, su figuración no llega a corresponderse totalmente con un ambiente paradisiaco. A medida que el narrador descubre el paisaje sinuoso se van anudando, a su vez, una secuencia de imágenes inquietantes: "platos y tazas llameaban en sus manos trigueñas: de vez en cuando un cuchillo dentado asomaba, luminoso y feliz, pero en todo caso como ensangrentado" (Rosero, 2007, p. 12), y de microrrelatos de asesinatos atroces, como el de la bomba en la iglesia que mata a los padres de Gracielita - la empleadaniña de Geraldina-, que desdibujan la idea de estar ubicados en el lugar amoroso o místico que proponen los míticos jardines del imaginario colectivo universal.

Si bien quien observa y cuenta el jardín lo tiñe de sus deseos y emociones, proyectándolo como lugar que protege de la amenaza exterior, no deja de apreciarse la mirada testimonial que descubre la violencia como fenómeno latente, que acecha el ambiente preciado. Este tratamiento del espacio ficcional da, desde el inicio de la novela, un carácter consciente y crítico a la situación real que viven los personajes. La tensión freudiana entre el principio del placer, representado por las ensoñaciones sensuales del protagonista, y el instinto de muerte, incorporado por las fuerzas militares, como desencadenantes de la narración, se exterioriza con lucidez en los modos como el jardín se escenifica de principio a fin en el relato.

El "espacio feliz" del jardín adquiere capital sentido en la escritura de Rosero porque se propone como imagen totalizante de la paulatina degradación que sufren los personajes y los lugares que habitan, a manos de los ejércitos que revientan el pueblo. El jardín de la casa no solo introduce lo narrado, sino que también se ubica como epílogo. Es una entidad ambivalente, que recoge en sí misma las dos caras de la realidad de los pobladores: la primera, al inicio del relato, llena de luz y esperanza, pese a los antecedentes violentos; la segunda, en las páginas finales, invadida 
de oscuridad y absoluta fatalidad. En efecto, el último lugar de la realidad ficcional, que también recorremos al lado del anciano-narrador, es el mismo jardín de las primeras líneas, pero transformado ahora en topos horrendus. El Jardín de las Delicias, como bien podría nombrarse el espacio que inaugura la novela, muta en los párrafos finales en un Jardín de la Náusea, que provoca la arcada ante el panorama repulsivo de la muerte bestial y de la anulación total del sujeto:

Fui al huerto [...] Allí estaba la piscina; allí me asomé como a un foso: en mitad de las hojas marchitas que el viento empujaba, en mitad del estiércol de pájaros, de la basura desparramada, cerca de los cadáveres petrificados de las guacamayas, increíblemente pálido yacía el cadáver de Eusebito [...] Pensé en Geraldina y me dirigí a la puerta de vidrio, abierta de par en par [...] pude entrever los quietos perfiles de varios hombres, todos de pie [...] Entre los brazos de una mecedora de mimbre, estaba abierta a plenitud, desmadejada, Geraldina desnuda, la cabeza sacudiéndose a uno y otro lado, y encima uno de los hombres la abrazaba, uno de los hombres hurgaba a Geraldina, uno de los hombres la violaba: todavía demoré en comprender que se trataba del cadáver de Geraldina (Rosero, 2007, pp. 201-202).

Si el simbolismo de la mujer se identifica con la tierra, la vida y la fertilidad, resulta perfectamente asociable con la representación metafórica del jardín como "auténtica matriz, en cuyo espacio se aprisionan los elementos primordiales: la piedra y el agua, los pájaros y las plantas" (Aínsa, 2006, p. 180). De esta manera, confluye, alegóricamente, en la narrativa de Rosero un jardín/mujer, una mujer/jardín que de refugio para la música, el placer y el anhelo, pasa a convertirse en territorio del caos, de la perturbación, expuesto al salvajismo exterior. La transformación abyecta del jardín intensifica su valor semántico cuando lo coligamos a la humillación que sufre el cuerpo de Geraldina, un refugio cálido que es desgarrado, disociado de su condición ontológica y socavado por la fuerza bestial, aspecto que aumenta la repulsión del lector contra quienes han llegado a tal nivel de depravación.

El cadáver de Eusebito, tirado entre los residuos, y la profanación del cuerpo de Geraldina evidencian el núcleo mismo de la malevolencia gubernativa, de quienes manipulan lo político como máquina de muerte y degradación. La destrucción del pueblo como cuerpo social se asimila en los cadáveres saboteados, humillados: quizás por el ejército nacional, quizás por la guerrilla, quizás por los paramilitares, por todos a la vez. El ensañamiento contra el cuerpo de los personajes es una forma de implantar 
un clima de horror en el pueblo. Evidentemente, el relato ejemplifica la manipulación del miedo y sus derivados, horror y terror, con intención política. Si bien el miedo es emoción natural que surge espontáneamente ante la percepción de peligro, puede encauzarse y manipularse con fines precisos, relativizando de esta forma su condición primigenia. Se reconoce que como producto del artificio del poder, esta emoción anida en el corazón mismo de las relaciones políticas de los sistemas e ideologías. El miedo ha sido desde siempre elemento capital en el arte de gobernar (Robin, 2009).

En Los ejércitos, el miedo adquiere carácter político porque es usado y desviado hacia circunstancias que alteran nocivamente la vida del pueblo; se enraíza a los temores públicos, y sus efectos comprometen no solo la intimidad del narrador sino también la faceta social de toda la comunidad. La sensación de amenaza, el desamparo, el rencor, el horror, expresado por los personajes son manifestación explícita del miedo político. La escenificación de esta emoción a través de la visualidad de los cuerpos eviscerados demuestra un interés de dominación sobre el otro y de imponer un poder en detrimento del bienestar colectivo. De hecho, puede decirse que el efecto de las escenas de tortura y violación son mucho más poderosas que el de la amenaza directa de un arma, pues aboca al personaje a un estado de locura y hundimiento, a una especie de lento suplicio interior. El horror, en este sentido, no solo nulifica lo humano en los cadáveres avasallados del jardín, sino también en quien los presencia. Esta violencia horrorosa que no se conforma con dar muerte, sino que aniquila al otro en su condición humana misma, contamina el lugar natural y desfigura su poder protector. Aquí el jardín no es más la tentativa de organizar el espacio privado e inventar un mundo a imagen y semejanza de las ensoñaciones propias, como tampoco resguarda contra la amenaza de afuera.

A continuación, por la extensión de este artículo, abordamos brevemente otros topos asociados con el espacio natural: el agua y las oquedades. La escritura los significa como figuras representativas del miedo asociado con la violencia política. Veamos: "Allí me asomé como a un foso", dice el personaje de Rosero en el último pasaje citado, equiparando la piscina del jardín con un hoyo de muerte, pues en el fondo de esta se encuentra el cadáver de Eusebito. La "pequeña piscina redonda" (Rosero, 2007, p. 16), remedo del simbólico estanque de los jardines clásicos, que al inicio de la novela aparece en medio del huerto, con sus aguas azuladas, armonizando con los colores, la desnudez y las risas, después del paso de "los ejércitos" se 
disgrega de su imagen húmeda e iridiscente. Como pozo de agua agotada, la piscina del jardín se transforma en una oquedad seca y ominosa, en un depósito de cadáveres animales y humanos que desbarata la simbología poética de la fuente, del agua, como elemento primordial de vida y renovación.

El motivo de la fosa es recurrente en la novelística que aborda la violencia sociopolítica. Pozos, hoyos, abismos, fosas comunes aparecen en la narrativa latinoamericana como honduras sintomáticas del clima de horror que se ha instalado como lógica de vida en sociedades de diferentes países. La escalada de la violencia del narcotráfico en México, por ejemplo, es indagada por Bencomo (2015) a partir del tópico literario del pozo. Para la investigadora, esta hondura de la muerte es signo que define la realidad caótica y la zozobra social mexicana de las últimas dos décadas. La fosa, como interioridad abismal, alimentada por los cuerpos anónimos que se descomponen en ella, es, por antonomasia, el lugar del miedo. La sensación de la persona y de la sociedad de encontrarse al borde de un precipicio, frente a un vacío de sentido, toma fuerte representación en este tipo de oquedades, en los pozos secos y demás abismos aciagos (Bencomo, 2015, p. 49). El estado emocional de las poblaciones constreñidas por la barbarie desmesurada se descifra en la fosa, ícono preciso de los escenarios de muerte, tortura y desaparición.

Acuciosa y hambrienta, la fosa, como especie de hoyo negro, se traga todo rayo de luz que intente aventurarse en ella, agrega Sustaita (2016). La imposibilidad de adentrarse visualmente en un espacio oscuro provoca pavor. "El espanto no es aquello que pueda verse, sino el hecho de que no pueda verse nada" (p. 353). Ciertamente, aquello que ha sido presa de la destrucción más espantosa adquiere el carácter de lo "inmirable", sacude violentamente lo íntimo de quien lo observa. La opacidad de la fosa, en este orden, es signo del horror; en su profundidad se oculta lo que no quiere que se mire, lo que se busca ocultar a la percepción de los otros. La víctima que es lanzada al pozo seco, o en el caso de la novela de Rosero, el niño que yace en el fondo de la piscina-fosa, señala la condición infame de quien muere en la más absoluta oscuridad, en el desamparo y el anonimato.

La sequía del pozo, las aguas agotadas, evocan el simbolismo que adoptan los afluentes en las novelas que vamos abordando. Los ríos, que surcan el campo y la ciudad, se alejan también de su condición natural, dadora de vida, para convertirse en escenarios privilegiados de fragmentación y muerte. Si en determinado momento, en la narrativa de 
la selva y en la de tema rural, los ríos colombianos - Cauca, Magdalena, Amazonas, etc. - arrastran plantas, flores, semillas, y su dimensión caótica se asocia al propio poder de sus cauces, en los textos que abordan la violencia política, estos afluentes se han transformado en arterias de sangre estancada que transportan cuerpos muertos y envenenan los espacios que recorren (Jeftanovic, 2007).

El motivo del agua ha sido recurrente en la literatura como medio que matiza la visión horrorosa de la muerte. Morir ahogado en las aguas de un río es circunstancia que tornó en ícono literario desde la Ofelia de Shakespeare. Al respecto, Bachelard (2000) sostiene que "el agua es el elemento de la muerte joven y bella, de la muerte florecida y, en los dramas de la vida y de la literatura, es el elemento de la muerte sin orgullo ni venganza" (p. 128). El suicidio femenino se ha ligado primordialmente con lo acuático. Por caso, en el mito colombiano La laguna de Guatavita, la consorte del Cacique, al sentirse humillada públicamente por este, se ahoga junto con su pequeña hija. Este acto la convierte en una deidad del agua, asociada con el dragoncillo tutelar de la laguna. En el relato, la injusticia y el desamor confieren un valor simbólico a los modos de morir en el agua por mano propia.

La metáfora de la muerte asociada con el agua, lo femenino, lo mítico, ha respondido a un imaginario poético que busca matizar la perturbación que causa el cadáver ahogado. Empero, en una especie de "estética de oposición”, las novelas motivo de estudio, que fijan la atención en los ríos y afluentes como cuna última del cuerpo moribundo, invierten toda imagen idílica que el agua pueda aportar. El río es, escuetamente, un lecho que recibe los cuerpos descuartizados, sus aguas los engullen cual pellejos de bestias muertas. En Los derrotados, si bien la imagen del río Medellín se vincula al elemento femenino y adquiere cierta connotación mítica con la figuración de la Beatriz de Dante, sus aguas son sinónimo de lo pestilente, hacen parte de una geografía de la podredumbre, de un "paisaje anormal":

[... ] surgía una especie de Beatriz que había descendido del Paraíso para deambular por los diversos infiernos de Medellín. Una mujer mestiza, de cabellos crespos y largos, vestida con sedas blancas bajo las cuales se transparentaban dos pezones erguidos y un amplio pubis oscuro [...] Beatriz se columpiaba sobre las aguas sucias del río en el puente Colombia, cenaba empelota con parapléjicos viciosos [...] entraba al matadero de Acevedo y lloraba ante los terneros descuartizados que se desangraban en sus piernas abiertas (Montoya, 2012, p. 107). 
Aquí la habilidad descriptiva da forma a una alegoría de lo repugnante. Los epítetos hábilmente utilizados — sedas blancas, pubis oscuro, parapléjicos viciosos, terneros desangrándose, aguas sucias- no solo ubican el río en medio de un paisaje marginal, sino que, asimismo, producen una atmósfera lúgubre, indicativa de lo horroroso: uno de "los rostros más genuinos de Medellín” (p. 107). Si el río ha sido visto como tránsito de vida, simbolizado por el agua como umbral existencial y elemento de purificación, en la narrativa de los lugares de lo atroz es una veta oscura en la memoria y la historia de una ciudad y del país. Parafraseando a Jeftanovic (2007), en un descarnado uso de la metáfora, la historia colombiana, como el río de Heráclito, es un río que nunca se detiene, caracterizado por la podredumbre y el tránsito permanente de la muerte. Sus aguas son el flujo doliente y mortuorio de quienes han sucumbido desde los inicios del país hasta nuestros días. En su pestilencia y hedor se rastrea el recorrido de la violencia y el crimen como componentes invariables del devenir nacional, de lo que nos condiciona como colombianos.

En orden a las ideas desarrolladas a lo largo de este texto, podemos concluir que las novelas coinciden en hacer de los escombros una memoria alterna a los monolíticos relatos históricos. La escritura aprovecha sitios icónicos de la urbe y los negros recuerdos que tiene la población de territorios sometidos a la barbarie para decantarlos como "topos del miedo". Contar el pasado consiste en espacializarlo, ubicarlo en las cartografías urbanas que la ficción incorpora. Las metáforas del Centro Histórico de Bogotá, sometido por las llamas del terror, sitúa la historia en un tiempo y espacio precisos; también desacopla los moldes que han dado forma a registros rígidos, cifras abstractas de muertes y pérdidas materiales, para rehacerlos y rellenarlos del sufrimiento personal: del espanto, la rabia o la impotencia. Ante los escuetos hechos colectivos que componen la Historia, los escritores reconocen que el ser humano no está diseñado para simpatizar con las generalizaciones; una cifra o descripción lacónica del pasado provoca comprensiones frías y distantes (Vásquez, 2018). Por esta razón, las novelas enlazan siempre los sucesos públicos a la ficcionalización de una memoria emocional. Reescribir los lugares icónicos como sitios vividos restituye el carácter individual, íntimo y relativo de la historia colombiana.

Los espacios familiares son, asimismo, metáforas continuativas de la realidad opresiva que se vive más allá de sus puertas y ventanas. La habitación de infancia, por caso, trastoca su tradicional simbolismo de cuna 
para el refugio por espacio en crisis, donde se desarticulan las relaciones entre padres e hijos, a causa de los acontecimientos políticos y del desafecto por la tradición familiar. En las narrativas, el sitio primigenio es destruido simbólica y materialmente; los personajes, en consecuencia, no encuentran dónde enraizarse como sujetos sociales; por principio moral, ellos rechazan lo que el país y la familia ofrecen como referente de identidad cultural y valor nacional. Igualmente, la perturbación mórbida que en la realidad ficcional sufre el jardín, como sitio personal, lo disocia de su condición protectora y placentera. La confrontación que las novelas proponen de un antes y un después del paso de la violencia por campos y veredas devela el poder aniquilador del sujeto político. La inmersión de la narrativa en los ríos que llevan cuerpos mutilados, en las oquedades que desaparecen lo humano de la víctima descubre sin dificultad que la violencia política es la verdadera arquitecta del paisaje colombiano. La narración dolida de los protagonistas convierte los lugares en un estado de ánimo, en lenguaje que descifra la conciencia de quien lo pierde todo. Los lugares abyectos, se puede sintetizar, son sintomáticos de las sociedades contemporáneas: contaminadas, enfermas, por la violencia extrema que las amenaza hasta sus espacios más íntimos.

\section{Referencias Bibliográficas}

Aínsa, F. (2006). Del topos al logos: propuestas de geopoética. Madrid: Gedisa.

Bachelard, G. (2000). La poética del espacio. Buenos Aires: Fondo de cultura económica.

Bencomo, A. (2015). La palabra oblicua. Representación de la violencia en México. En

C. López Badano (Comp.). Periferias de la narcocracia. Ensayos sobre narrativas contemporáneas (pp. 35-50). Buenos Aires: Corregidor.

Campra, R. (1989). La selva en el damero: espacio literario y espacio urbano en América Latina. Pisa: Giardini.

De Certeau, M., Giard, L., Mayol, P. (2010). La invención de lo cotidiano 1. Artes de hacer. México: Universidad Iberoamericana.

Gamboa, S. (2012). Plegarias nocturnas. Barcelona: Mondadori.

Giraldo, L. M. (2001). Ciudades escritas. Literatura y ciudad en la narrativa colombiana. Bogotá: Andrés Bello.

Jeftanovic, A. (2007). Mapocho de Nona Fernández: la ciudad entre la colonización y la globalización. Chasqui 36 (2), pp. 73-84.

Montoya, P. (2012). Los derrotados. Medellín: Sílaba.

Nora, P. (1984). Les lieux de mémoire. I. La République. Paris: Gallimard.

Restrepo, L. (2004). Delirio. Bogotá: Alfaguara.

Robin, C. (2009). El miedo. Historia de una idea política. México: Fondo de Cultura Económica. 
Rosero, E. (2007). Los ejércitos. Barcelona: Tusquets.

Sustaita, A. (2016). La pantalla y la fosa. Modelos estéticos de la necropolítica en el México actual. Veredas. Revista del pensamiento sociológico 32, pp. 347-361.

Torres, M. (2012). El incendio de abril. Bogotá: Alfaguara.

Vásquez, J. G. (2011). El ruido de las cosas al caer. Bogotá: Alfaguara.

Vásquez, J. G. (2018). Viajes con un mapa en blanco. Madrid: Alfaguara. 